\title{
Treatment options for patients with HR+/HER2- advanced breast cancer during the COVID-19 pandemic: dose reduction of ribociclib does not diminish efficacy
}

\author{
Joyce O'Shaughnessy ${ }^{1,2}[$
}

Received: 28 April 2020 / Accepted: 9 May 2020 / Published online: 20 May 2020

(c) The Author(s) 2020

\section{To the editor,}

The COVID-19 pandemic poses unprecedented challenges to the field of oncology. I read with great interest the recent recommendations outlined by Deitz et al. for patients with breast cancer during the COVID-19 pandemic [1]. For patients with hormone receptor-positive/human epidermal growth factor receptor 2-negative (HR+/HER2-) metastatic breast cancer, it is recommended that use of targeted oral therapies be weighed against the risk of adverse events and that dose reductions can minimize treatment-related toxicities. This was followed by the statement "dose reduction of palbociclib does not diminish efficacy."

Currently, there are three CDK4/6 inhibitors approved for the treatment of HR+/HER2- metastatic breast cancer. To provide additional information for health care professionals in their decision-making, I would like to point out that dose reduction of the CDK4/6 inhibitor ribociclib also does not diminish efficacy. An analysis of patients with advanced breast cancer in the phase III MONALEESA-2, -3 , and -7 trials who received ribociclib as initial endocrine-based therapy for advanced breast cancer showed that median progression-free survival was comparable between patients who had no dose reduction vs patients with $\geq 1$ dose reduction (MONALEESA-2: 27.7 months vs 25.3 months; MONALEESA-3: not estimable vs not estimable; MONALEESA-7: 23.8 months vs 27.5 months) [2]. It has also been reported separately that ribociclib demonstrated a significant overall survival benefit over endocrine

This comment refers to the article available online at https://doi. org/10.1007/s10549-020-05644-z.

Joyce O'Shaughnessy

joyce.oshaughnessy@usoncology.com

1 US Oncology Research, Inc., The Woodlands, TX, USA

2 Texas Oncology/Baylor University Medical Center, Dallas, TX, USA therapy alone in phase III trials (MONALEESA-3 and -7; MONALEESA-2 overall survival data is immature at this time) [3]. In all three trials, the most frequent adverse event (all grades) for patients with no dose reduction and $\geq 1$ dose reduction was neutropenia. The most common reason for dose reduction was an adverse event.

Awareness of all available options may help in making treatment decisions for individual patients. I hope the information provided here can aid in that process.

Funding Editorial support was paid for by Novartis.

\section{Compliance with ethical standards}

Conflict of interest Dr. O'Shaughnessy reports AbbVie Inc., Agendia, Amgen Biotechnology, AstraZeneca, Bristol-Myers Squibb, Celgene Corporation, Eisai, Genentech, Genomic Health, GRAIL, Immunomedics, Heron Therapeautics, Ipsen Biopharmaceuticals, Jounce Therapeutics, Lilly, Merck, Myriad, Novartis, Ondonate Therapeutics, Pfizer, Puma Biotechnology, Prime Oncology, Roche, Seattle Genetics, Syndax Pharmaceuticals.

Ethical approval This article does not contain any studies with human participants or animals performed by any of the authors.

Informed consent Not applicable.

Open Access This article is licensed under a Creative Commons Attribution 4.0 International License, which permits use, sharing, adaptation, distribution and reproduction in any medium or format, as long as you give appropriate credit to the original author(s) and the source, provide a link to the Creative Commons licence, and indicate if changes were made. The images or other third party material in this article are included in the article's Creative Commons licence, unless indicated otherwise in a credit line to the material. If material is not included in the article's Creative Commons licence and your intended use is not permitted by statutory regulation or exceeds the permitted use, you will need to obtain permission directly from the copyright holder. To view a copy of this licence, visit http://creativecommons.org/licenses/by/4.0/. 


\section{References}

1. Deitz JR, Moran MS, Isakoff SJ et al (2020) Recommendations for prioritization, treatment and triage of breast cancer patients during the COVID-19 pandemic. Breast Cancer Res Treat. https ://doi.org/10.1007/s10549-020-05644-z

2. Beck JT, Neven P, Sohn J et al (2019) Ribociclib treatment benefit in patients with advanced breast cancer with $\geq 1$ dose reduction: Data from the MONALEESA-2, -3 , and -7 trials. Cancer Res 79(4S):P6-18-06
3. NCCN Clinical Practice Guidelines in Oncology for Breast Cancer V.3.2020.

Publisher's Note Springer Nature remains neutral with regard to jurisdictional claims in published maps and institutional affiliations. 